\title{
Effect of ecdysteroids on oogenesis in the freshwater crab Travancoriana schirnerae Bott, 1969 (Crustacea: Gecarcinucidae)
}

\section{Sudha Devi Arath Raghavan* and Aswani Ayanath}

Department of Zoology. Mary Matha Arts \& Science College. Wayanad. Kerala 670 645. India.*Email: arsudhadevi@gmail.com.

\begin{abstract}
This study evaluated the reproductive performance of female Travancoriana schirnerae Bott, 1969 (Crustacea: Gecarcinucidae) administered with 20-0H ecdysone during different phases of the oogenic cycle. The effect of administration was evaluated by comparing the mean gonadosomatic index, oocyte diameter, oocyte proportion values and histological features of the control and concurrent control ovaries with those of the experimentals. The results clearly indicated that 20-0H ecdysone can stimulate ovarian growth and maturation in all phases of the oogenic cycle, though it caused statistically significant effects only during the early and middle vitellogenic phases, evidenced from the accelerated gonadosomatic index, oocyte diameter and oocyte proportion values, occurrence of vitellogenic oocytes in avitellogenic and previtellogenic ovaries, increased degree of yolk deposition and proliferation of gonia in the experimental ovaries compared to the controls. The outcome of this study is quite promising in the aquaculture practice of this locally abundant edible freshwater crab which forms a cheap protein substitute for the malnourished tribes/poor people of Wayanad.
\end{abstract}

Keywords: 20-OH ecdysone; Freshwater crab; Oogenesis; ovarian growth and Travancoriana schirnerae.

\section{Introduction}

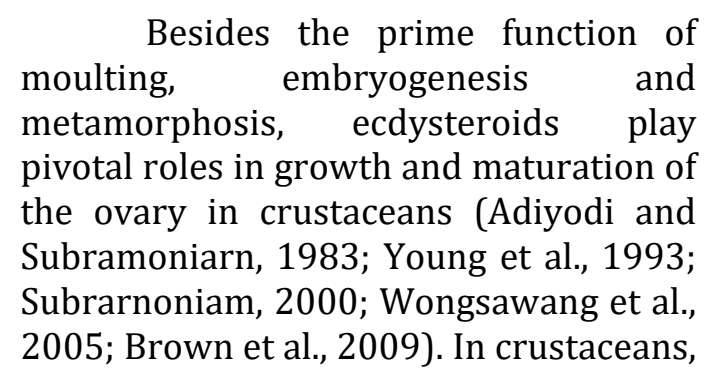

the Y-organ or the moulting gland synthesizes and secretes ecdysteroids from dietary cholesterol (Chang, 1985). Yudin et al. (1980) reported a direct relation between the circulating titre of ecdysteroids and vitellogenesis in the blue crab Callinectes sapidus. In Carcinus maenas, Lachaise et al. (1981) demonstrated an enhancement in ecdysteroid titre with stage of 
maturation of the ovary. In the amphipod Orchestia gammarella, removal of $\mathrm{Y}$ organ in postmoult stage restrained the commencement of vitellogenesis (Blanchet, 1982). In Acanthonyx lunulatus (Chaix and De Reggi, 1982) and Macrobrachium rosenbergii (Laufer et al., 1993), the hemolymph titre of ecdysteroids was found at its peak in females with ovaries in late maturation phase. Okumura et al. (1992) found a perceptible rise in the hemolymph titre of ecdysteroid with the stage of development of the ovary in the reproductive moult cycle of Macrobrachium nipponense. $\mathrm{Mu}$ et al. (2014) have shown high ecdysteroid receptor expression in the ovaries of the crab Portunus trituberculatus after mating, signifying its role in ovarian growth and maturation. Gong et al. (2015) described three isoforms of ecdysteroid receptors in Scylla paramamosain ovary which possibly suggest the involvement of ecdysteroids in inducing ovarian growth and maturation. In the freshwater crab Barytelphusa cunicularis, Kale (2017) observed elevated values for ovarian index and oocyte diameter following $\beta$-estradiol administration.

Though literature is plenty regarding the role of ecdysteroids on reproduction in brachyurans, their functional role in the control of reproduction is divisive and mode of action on vitellogenesis is till now not determined, especially in freshwater brachyurans. In this context, the current research on the effect of exogenous administration of 20-0H ecdysone on growth and development of the ovary in a locally available edible freshwater crab, Travancoriana schirnerae Bott, 1969 (Crustacea: Gecarcinucidae), is undertaken.

\section{Methodology}

Adult females (carapace width 4.5-5.0 cm) with ovaries in various developmental stages were collected monthly for a period of one year (20172018) from rice fields near Ondayangadi (11 ${ }^{\circ} 49^{\prime} 20.3^{\prime \prime} \mathrm{N}$ and $\left.76^{\circ} 01^{\prime} 47.1^{\prime \prime} \mathrm{E}\right)$ and allowed to accustom with the controlled laboratory conditions (temperature $25^{\circ} \mathrm{C} \pm 2{ }^{\circ} \mathrm{C}$ and a photoperiod of $12 \mathrm{~h}$ light and $12 \mathrm{~h}$ dark) for 3-4 days. Crabs were fed daily once with boiled egg, pulses and decaying aquatic vegetation. Their carapace width and moult stages were determined by noting down the changes in the pleopod setae and the carapace texture.

The ecdysteroid (20-OH ecdysone) used in this experiment (Sigma Chemicals, USA) was dissolved in $10 \%$ ethanol $(1 \mathrm{mg} / 1 \mathrm{~mL})$. Individuals were divided into three groups; Group I ( $n=15$ ) which formed the initial control, were sacrificed on day one of the experiment. Group II, which received $10 \% \quad 10 \mu \mathrm{L} \quad$ ethanol/crab/injection formed the concurrent controls and Group III ( $\mathrm{n}=15$ each) which received 40 ng 20-OH ecdysone/injection/crab on days $1,7,14$, and 21 formed the experimentals. The injections were given through the arthrodial membrane of the coxa of the last walking leg. Both the concurrent controls and experimentals were sacrificed on the 28th day of the experiment. The body weights and wet weights of ovaries of control and experimental crabs were recorded to determine the Gonadosomatic Index (GSI).

For measurement of oocyte diameter, around 50 oocytes/ovary were chosen randomly and their diameters were measured using a calibrated ocular micrometer. The stage of maturation of the ovary was assessed from the colour of ovary, oocyte diameter and from microscopical examinations. Pieces of ovaries were fixed in Bouin's fluid, dehydrated in ascending grades of alcohol, infiltered and embedded in paraffin wax, sectioned and stained in Heidenhain's hematoxylin-eosin, observed and photographed under a Leica DM 500 Research Microscope. Data were presented as Mean \pm SD and 
analysed statistically using ANOVA. A probability value equal to or less than 0.05 was considered statistically significant.

\section{Results}

This study evaluated the reproductive performance of female T. schirnerae administered with 20-OH ecdysone during different phases of oogenesis. The effect of administration was evaluated by comparing the GSI, oocyte diameter, oocyte proportion values and histology of the ovaries of control and concurrent controls with those of the experimentals.

\section{Effect of 20-0H ecdysone administration during avitellogenic phase \\ Though 20-OH ecdysone administration caused a spurt in GSI}

$(0.238 \mu \mathrm{m} \pm 0.02 \mu \mathrm{m})$ and mean oocyte diameter $(81.68 \mu \mathrm{m} \pm 1.95 \mu \mathrm{m})$ values than the initial controls $(0.214 \mu \mathrm{m} \pm 0.02$ $\mu \mathrm{m}$ and $76.14 \mu \mathrm{m} \pm 5.17 \mu \mathrm{m})$ and concurrent controls $(0.223 \mu \mathrm{m} \pm 0.02 \mu \mathrm{m}$ and $79.49 \mu \mathrm{m} \pm 3.05 \mu \mathrm{m}$, respectively), these values were not significant statistically (Table 1). Both control and treated ovaries showed normal development with oogonia in the germinal zone and the chromatin nucleolus (CN) and perinuclear (PN) stage oocytes towards the periphery. However, the histological architecture of injected crabs demonstrated the presence of primary (early) vitellogenic (PV) oocytes (5\%) indicating signs of vitellogenesis in avitellogenic ovaries, a reduction in the proportion of shrunken follicles and atretic oocytes and a mild increase in proliferating oocytes (oogonia) (56\%) in comparison to the control groups $(53 \%$ and $54 \%$, respectively) (Figures $1 \mathrm{~A}, 2 \mathrm{~A}-\mathrm{F}$ ).

Table 1. Comparison of GSI and mean oocyte diameter of control and treated T. schirnerae during various phases of development of the ovary.

\begin{tabular}{|c|c|c|c|c|c|}
\hline \multirow{2}{*}{$\begin{array}{l}\text { Phases of } \\
\text { oogenesis }\end{array}$} & \multirow{2}{*}{ Group } & \multicolumn{2}{|c|}{ Gonadosomatic index } & \multicolumn{2}{|c|}{ Mean oocyte diameter $(\mu \mathrm{m})$} \\
\hline & & Mean \pm SE & F value & Mean \pm SE & F value \\
\hline $\begin{array}{l}\text { Avitellogenic (April- } \\
\text { May) }\end{array}$ & $\begin{array}{l}\text { Control } \\
\text { Concurrent control } \\
20 \text { E treated }\end{array}$ & $\begin{array}{l}0.214 \pm 0.02 \\
0.223 \pm 0.02 \\
0.238 \pm 0.02\end{array}$ & $\begin{array}{l}0.072 \\
0.764\end{array}$ & $\begin{array}{l}76.14 \pm 5.17 \\
79.49 \pm 3.05 \\
81.68 \pm 1.95\end{array}$ & $\begin{array}{l}0.142 \\
1.097\end{array}$ \\
\hline $\begin{array}{l}\text { Previtellogenic (Jun- } \\
\text { Sep) }\end{array}$ & $\begin{array}{l}\text { Control } \\
\text { Concurrent control } \\
\text { 20E treated }\end{array}$ & $\begin{array}{l}0.297 \pm 0.09 \\
0.302 \pm 0.05 \\
0.328 \pm 0.05\end{array}$ & $\begin{array}{l}0.002 \\
0.059 \\
\end{array}$ & $\begin{array}{l}391.01 \pm 2.86 \\
394.57 \pm 5.58 \\
398.12 \pm 12.30 \\
\end{array}$ & $\begin{array}{l}0.612 \\
1.345\end{array}$ \\
\hline $\begin{array}{l}\text { Early vitellogenic } \\
\text { (Oct- Nov) }\end{array}$ & $\begin{array}{l}\text { Control } \\
\text { Concurrent control } \\
\text { 20E treated }\end{array}$ & $\begin{array}{l}0.453 \pm 0.02 \\
0.462 \pm 0.01 \\
0.534 \pm 0.02\end{array}$ & $\begin{array}{l}0.069 \\
7.783^{*}\end{array}$ & $\begin{array}{l}491.98 \pm 1.37 \\
500.76 \pm 12.45 \\
506.36 \pm 2.89\end{array}$ & $\begin{array}{l}1.429 \\
24.136^{*}\end{array}$ \\
\hline $\begin{array}{l}\text { Middle vitellogenic } \\
\text { (Dec-Feb) }\end{array}$ & $\begin{array}{l}\text { Control } \\
\text { Concurrent control } \\
\text { 20E treated }\end{array}$ & $\begin{array}{l}1.127 \pm 0.08 \\
1.206 \pm 0.07 \\
1.326 \pm 0.09\end{array}$ & $\begin{array}{l}0.454 \\
4.615^{*}\end{array}$ & $\begin{array}{l}780.30 \pm 33.04 \\
801.006 \pm 20.03 \\
958.84 \pm 35.34\end{array}$ & $\begin{array}{l}0.230 \\
13.477^{*}\end{array}$ \\
\hline $\begin{array}{l}\text { Late vitellogenic } \\
\text { (Mar) }\end{array}$ & $\begin{array}{l}\text { Control } \\
\text { Concurrent control } \\
20 \mathrm{E} \text { treated }\end{array}$ & $\begin{array}{l}4.243 \pm 0.26 \\
4.329 \pm 0.37 \\
4.415 \pm 0.33 \\
\end{array}$ & $\begin{array}{l}0.038 \\
0.149\end{array}$ & $\begin{array}{l}1401.79 \pm 40.63 \\
1423.68 \pm 17.52 \\
1469.29 \pm 13.22 \\
\end{array}$ & $\begin{array}{l}0.173 \\
1.695\end{array}$ \\
\hline
\end{tabular}

Level of significance $* \mathrm{P}<0.05$. 

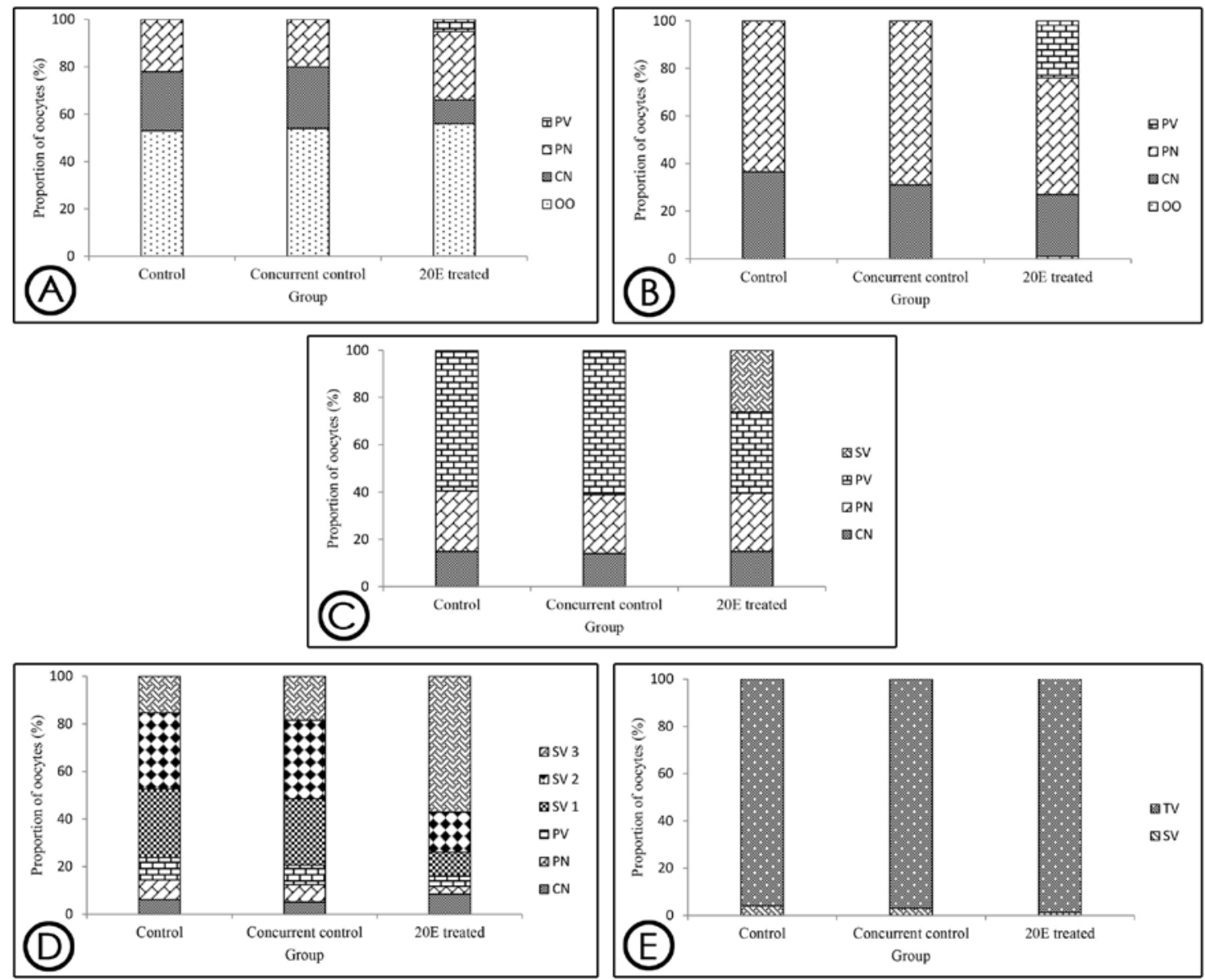

Figure 1. Effect of 20-OH ecdysone administration on oocyte proportion during various stages of maturation of the ovary in T. schirnerae. (A) Avitellogenic phase (B) Previtellogenic phase (C) Early vitellogenic phase (D) Middle vitellogenic phase (E) Late vitellogenic phase.

\section{Effect of administration of 20-0H ecdysone during previtellogenic phase \\ Administration of $20-\mathrm{OH}$} ecdysone during this phase did not cause a significant rise in GSI and mean oocyte diameter values $(0.328 \mu \mathrm{m} \pm 0.05 \mu \mathrm{m}$ and $398.12 \mu \mathrm{m} \pm 12.30 \mu \mathrm{m}$, respectively) with respect to the corresponding values of control $(0.297 \mu \mathrm{m} \pm 0.09 \mu \mathrm{m}$ and $391.01 \mu \mathrm{m} \pm 2.86 \mu \mathrm{m}$, respectively) and concurrent control crabs $(0.302 \mu \mathrm{m} \pm$ $0.05 \mu \mathrm{m}$ and $394.57 \mu \mathrm{m} \pm 5.58 \mu \mathrm{m}$, respectively) (Table 1). Nevertheless, histological analyses of injected ovaries revealed the presence of a large number of peripherally arranged primary vitellogenic oocytes (24\%) along with the CN (26\%) and PN stage oocytes (49\%) and proliferating gonia (1\%) arranged towards the centre of the ovary (Figures 1B). In addition, a follicular epithelium was noticed around the perinuclear and vitellogenic oocytes of treated crabs (Figures 3A-F). On the contrary, the control and concurrent control ovaries remained in the same stage of maturation till the end of the experimental period and contained only PN (64\% and 69\%, respectively) and CN oocytes (36\% and $31 \%$, respectively). 

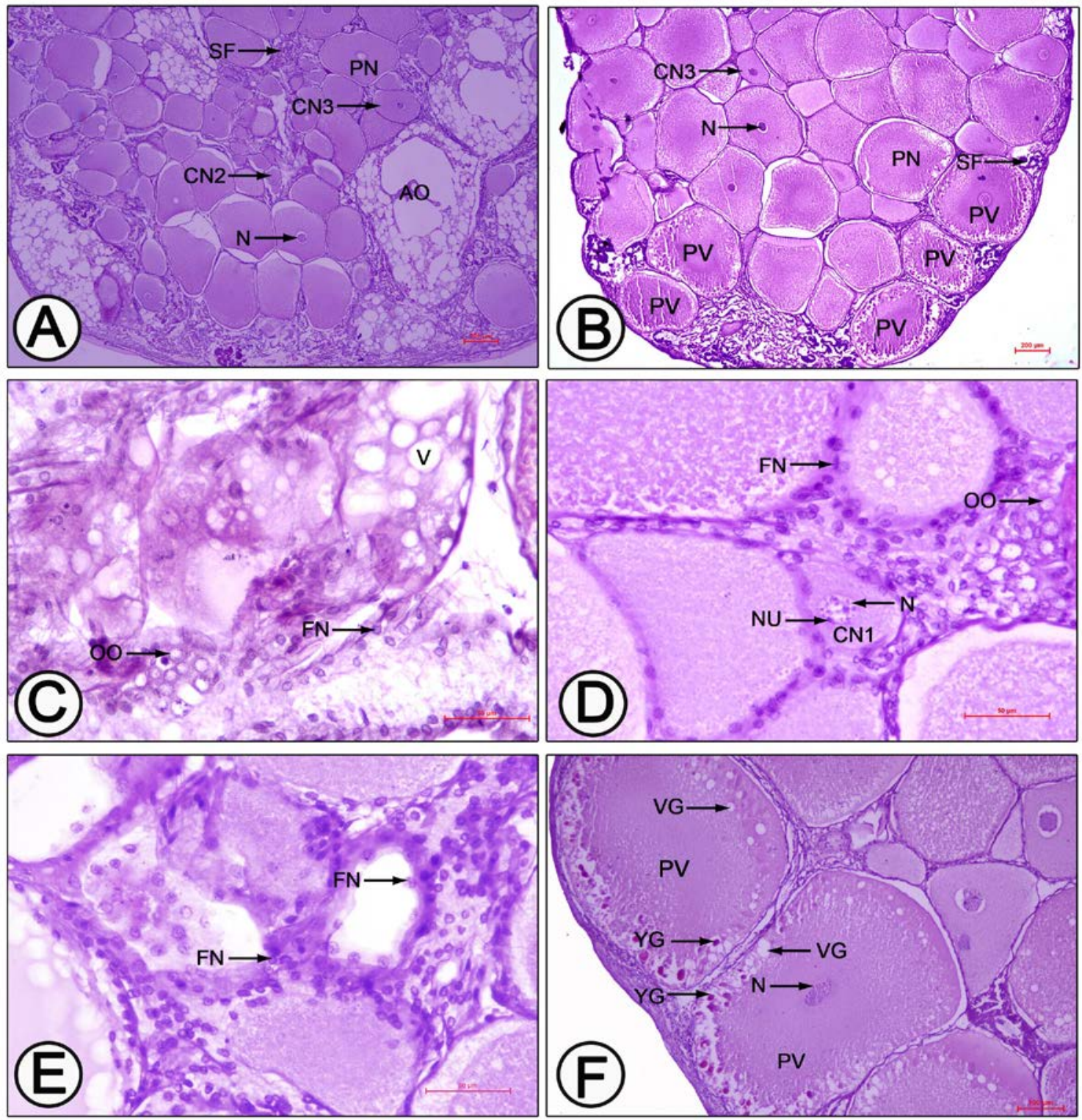

Figure 2. Longitudinal sections of control and treated ovaries in avitellogenic phase. (A) Control ovary depicting $\mathrm{CN}$ and PN oocytes, shrunken follicles and atretic oocytes (B) Injected ovary illustrating reduction in atretic oocytes and shrunken follicles (C-D) Ovaries of control and treated crabs portraying oogonial proliferation (E) Experimental ovary demonstrating follicle cell proliferation (F) Cortical alveoli in perinuclear stage oocytes of treated crabs. A0: Atretic oocyte; CN1: Chromatin nucleolus stage 1 oocyte; CN2: Chromatin nucleolus stage 2 oocyte; CN3: Chromatin nucleolus stage 3 oocyte; FN: Follicle nucleus; N: Nucleus; NU: Nucleolus; 00: Oogonia; PN: Perinuclear stage oocyte; PV: Primary vitellogenic oocyte; SF: Shrunken follicle; V: Vacuole; VG: Vacuolated globule; YG: Yolk globule.

\section{Effect of administration of 20-0H ecdysone during early vitellogenic phase}

Both GSI and mean oocyte diameter values escalated significantly $(0.534 \mu \mathrm{m} \pm 0.02 \mu \mathrm{m}$ and $506.36 \mu \mathrm{m} \pm$
$2.89 \mu \mathrm{m}$, respectively) $(\mathrm{P}<0.05)$ in crabs administered with 20-0H ecdysone during this phase. The initial and concurrent controls had the GSI and oocyte diameter values $0.453 \mu \mathrm{m} \pm 0.02$ $\mu \mathrm{m}$ and $491.98 \mu \mathrm{m} \pm 1.37 \mu \mathrm{m}$ and 0.462 
$\mu \mathrm{m} \pm 0.01 \mu \mathrm{m}$ and $500.76 \mu \mathrm{m} \pm 12.45 \mu \mathrm{m}$, respectively (Table 1 ). The most prominent feature of treated ovaries were the occurrence of many secondary (middle) vitellogenic (SV) oocytes (26\%) while the initial control and concurrent control ovaries were dominated by primary (early) vitellogenic oocytes (60\% and $61 \%$, respectively) with small percentages of PN (25\% each) and CN stages $(15 \%$ and $14 \%$, respectively) (Figures 1C). Another important feature of injected crabs was the incidence of oogonial nests in the germinal zone. Histological analyses of the ovaries of experimentals displayed more number of vacuolated globules $(15.00 \mu \mathrm{m}-28.70$ $\mu \mathrm{m})$ and large, highly basophilic yolk granules $(12.50 \mu \mathrm{m}-20.50 \mu \mathrm{m})$ in primary oocytes than their control groups $(12.80 \mu \mathrm{m}-23.50 \mu \mathrm{m}$ and $8.05 \mu \mathrm{m}$ $-13.25 \mu \mathrm{m}$, respectively) (Figures 4A-E).

\section{Effect of administration of 20-0H ecdysone during middle vitellogenic phase}

The GSI and oocyte diameter values were significantly high $(\mathrm{P}<0.05)$ in injected group $(1.326 \mu \mathrm{m} \pm 0.09 \mu \mathrm{m}$ and $958.84 \mu \mathrm{m} \pm 35.34 \mu \mathrm{m}$, respectively) compared to the initial $(1.127 \mu \mathrm{m} \pm 0.08$ $\mu \mathrm{m}$ and $780.30 \mu \mathrm{m} \pm 33.04 \mu \mathrm{m}$, respectively) and concurrent controls $(1.206 \mu \mathrm{m} \pm 0.07 \mu \mathrm{m}$ and $801.006 \mu \mathrm{m} \pm$ $20.03 \mu \mathrm{m}$, respectively) indicating that 20-OH ecdysone injection during this period can stimulate ovarian growth
(Table 1). Both the control $(76 \%$ and $79 \%)$ and treated ovaries (84\%) were dominated by secondary vitellogenic oocytes, however, treated ovaries had a significantly higher percentage of secondary vitellgenic stage 3 (SV3) oocytes (57\%) (with large vacuolated globules and yolk platelets) than the control groups $\quad(15 \%$ and $19 \%$ respectively). Proliferation of gonia and development of young oocytes ( $\mathrm{CN}$ and PN stage oocyte) were perceptible in the germinal zone of ovaries of injected crabs (Figures 1D, 5A-D).

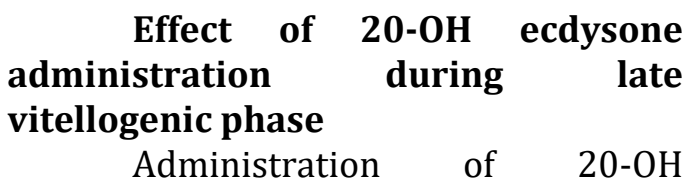

ecdysone in late vitellogenic phase did not cause a significant rise neither in the GSI $(4.415 \mu \mathrm{m} \pm 0.33 \mu \mathrm{m})$ nor in the mean oocyte diameter $(1469.29 \mu \mathrm{m} \pm$ $13.22 \mu \mathrm{m}$ ) values compared to the initial $(4.243 \mu \mathrm{m} \pm 0.26 \mu \mathrm{m}$ and $1401.79 \mu \mathrm{m} \pm$ $40.63 \mu \mathrm{m}$, respectively) and concurrent control values $(4.329 \mu \mathrm{m} \pm 0.37 \mu \mathrm{m}$ and $1423.68 \mu \mathrm{m} \pm 17.52 \mu \mathrm{m}$, respectively) (Table 1). Furthermore, there was not much difference in the histological appearance of the ovaries of control and experimental animals; both the control (96\% and $97 \%$, respectively) and experimental ovaries (99\%) were dominated by tertiary vitellogenic oocytes with a minor proportion of secondary vitellogenic oocytes (Figures 1E, 6A-D). 

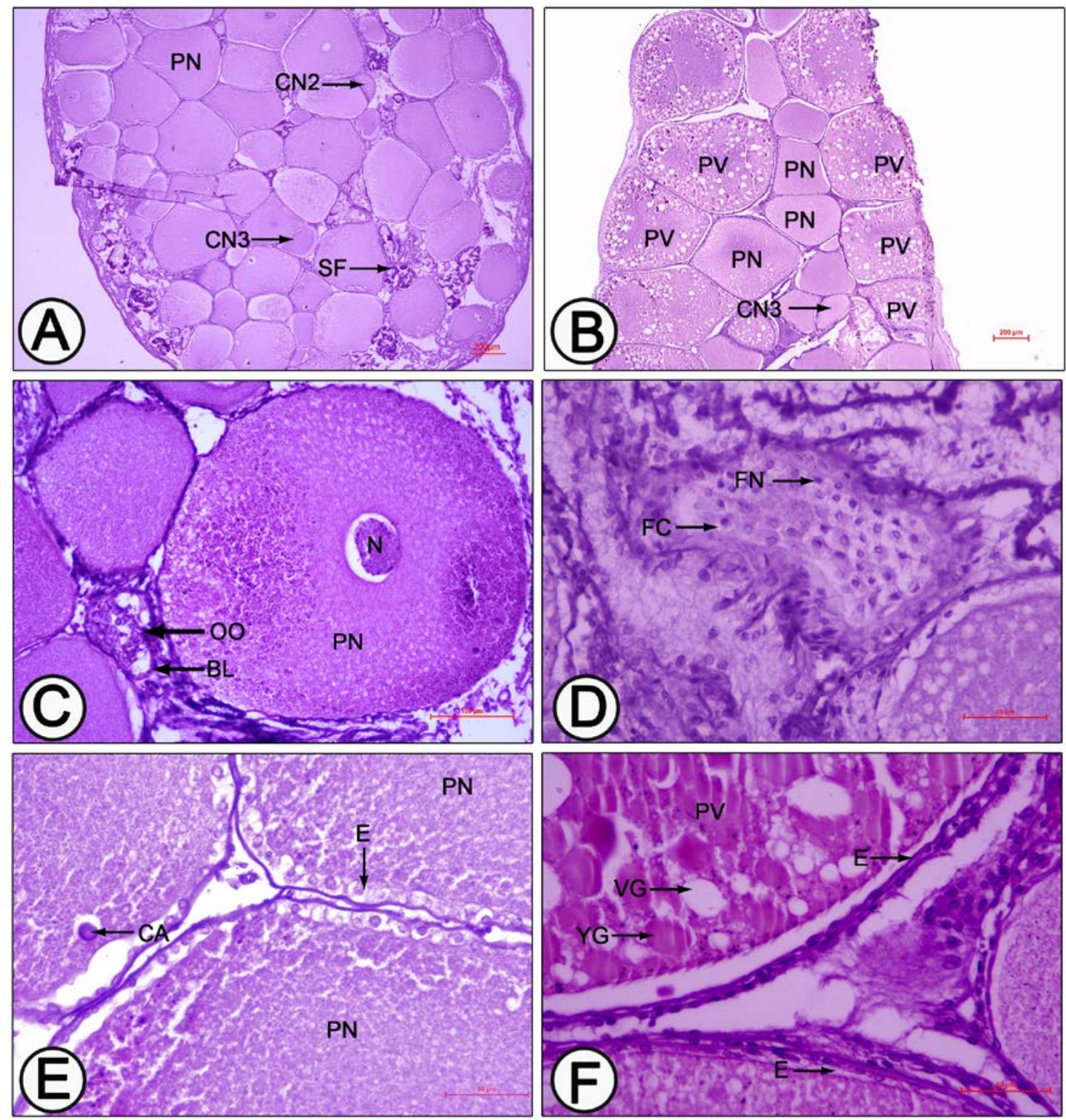

Figure 3. Light micrograph of ovary of control and 20-0H ecdysone administered crab during previtellogenic phase. (A) Ovary of control crabs populated by chromatin nucleolus and perinuclear stage oocytes (B) Primary vitellogenic oocytes in ovary of injected crab (C) Germinative islets in the ovary of treated crab (D) Treated ovary showing follicle cell proliferation (E) Follicular epithelium around the perinuclear oocytes in injected crab (F) Vitellogenic oocytes of experimental crab encircled by a bilayered follicular epithelium. BL: Basal lamina; CAA: Cortical alveoli; CN2: Chromatin nucleolus stage 2 oocyte; CN3: Chromatin nucleolus stage 3 oocyte; E: Epithelium; FC: Follicle cell; FN: Follicle nucleus; N: Nucleus; 00: Oogonia; PN: Perinuclear stage oocyte; PV: Primary vitellogenic oocyte; SF: Shrunken follicle; VG: Vacuolated globule; YG: Yolk globule. 

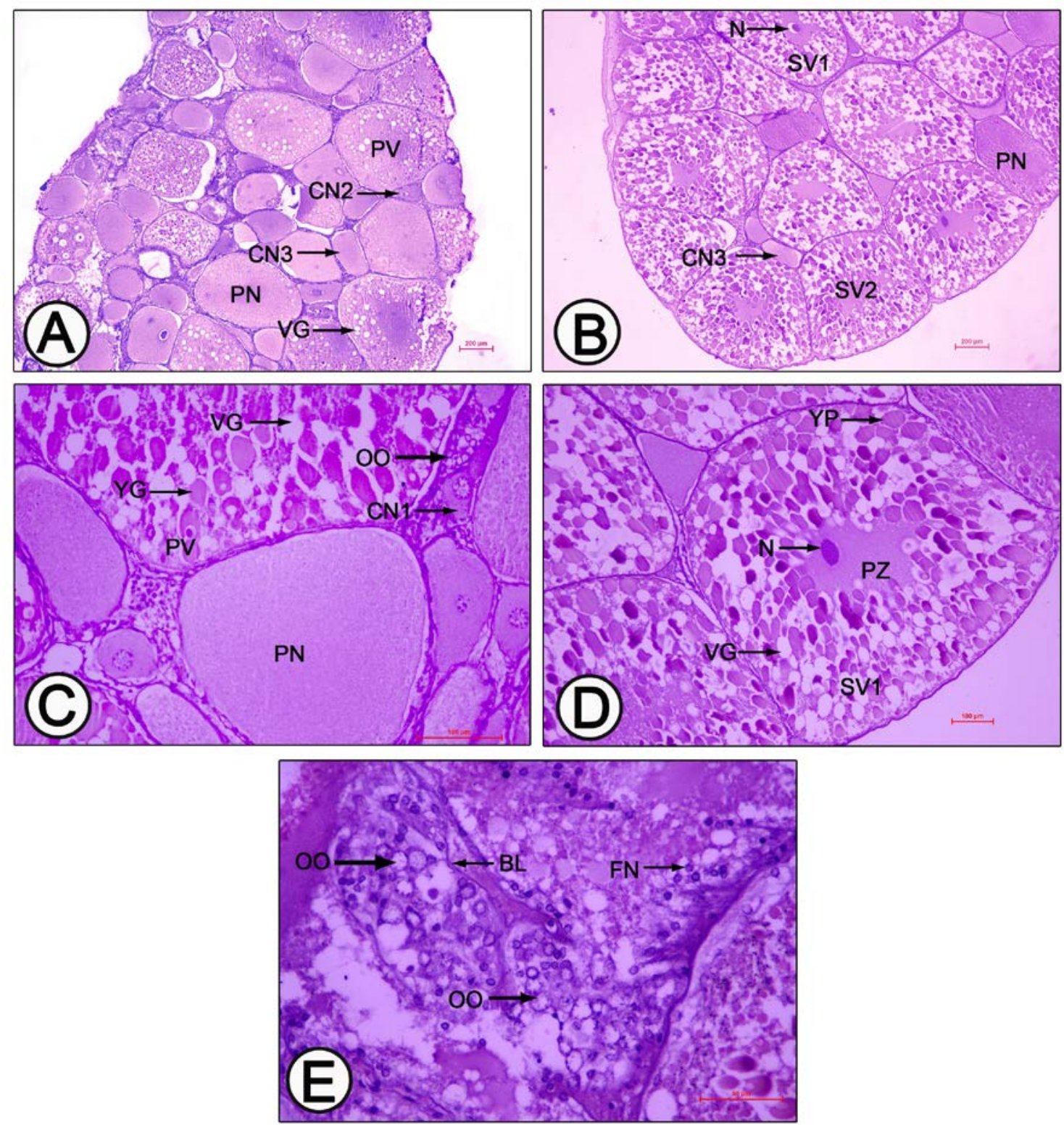

Figure 4. Ovaries of control and 20-0H ecdysone administered crabs during early vitellogenic phase. (A) Control ovary dominated by primary vitellogenic oocytes with vacuolated globules and yolk granules in the cortical region (B) Treated ovary dominated by secondary vitellogenic oocytes (C) Primary oocytes of experimentals with vacuolated globules, yolk globules and young oocytes (D) Vacuolated globules and yolk platelets in secondary oocytes of injected crab (E) Experimental ovary showing oogonial nest. BL: Basal lamina; CN1: Chromatin nucleolus stage 1 oocyte; CN2: Chromatin nucleolus stage 2 oocyte; CN3: Chromatin nucleolus stage 3 oocyte; FN: Follicle nucleus; N: Nucleus; 00: Oogonia; PN: Perinuclear stage oocyte; PV: Primary vitellogenic oocyte; PZ: Perinuclear zone; SV1: Secondary vitellogenic stage 1 oocyte; SV2: Secondary vitellogenic stage 2 oocyte; VG: Vacuolated globule; YG: Yolk globule; YP: Yolk platelet. 

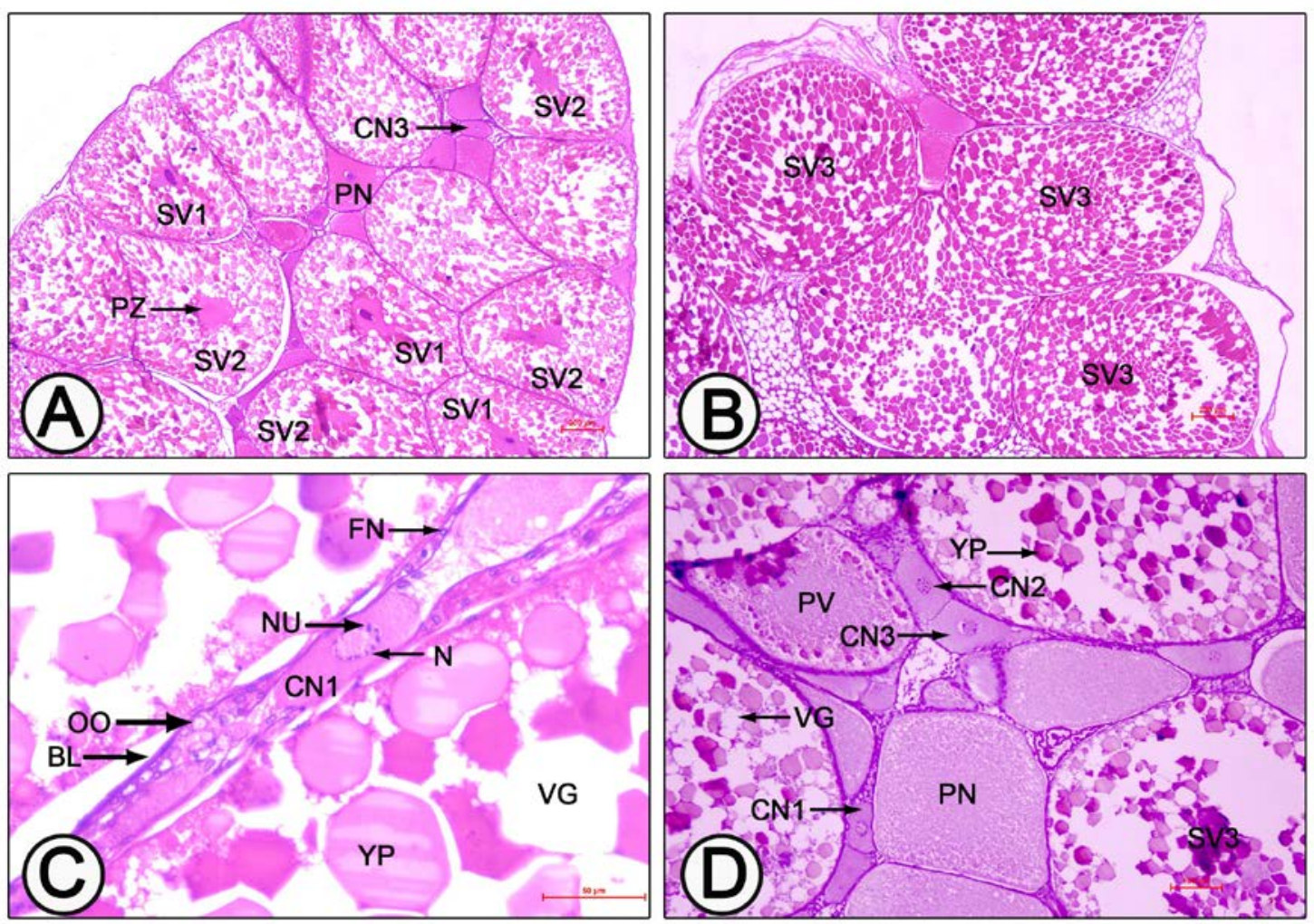

Figure 5. Light micrograph of ovary of control and 20-0H ecdysone administered crab during middle vitellogenic phase. (A) Control ovary dominated by SV1 and SV2 oocytes (B) Ovary of treated crab dominated by SV3 oocytes (C) Experimental ovary with large yolk platelets, vacuolated globules and proliferation of gonia in the germinal zone (D) Experimental vary showing development of young oocytes (CN and PN) from oogonia. BL: Basal lamina; CN1: Chromatin nucleolus stage 1 oocyte; CN2: Chromatin nucleolus stage 2 oocyte; CN3: Chromatin nucleolus stage 3 oocyte; FN: Follicle nucleus; N: Nucleus; NU: Nucleolus; 00: Oogonia; PN: Perinuclear stage oocyte; PV: Primary vitellogenic oocyte; PZ: Perinuclear zone; SV1: Secondary vitellogenic stage 1 oocyte; SV2: Secondary vitellogenic stage 2 oocyte; SV3: Secondary vitellogenic stage 3 oocyte; VG: Vacuolated globule; YP: Yolk platelet. 

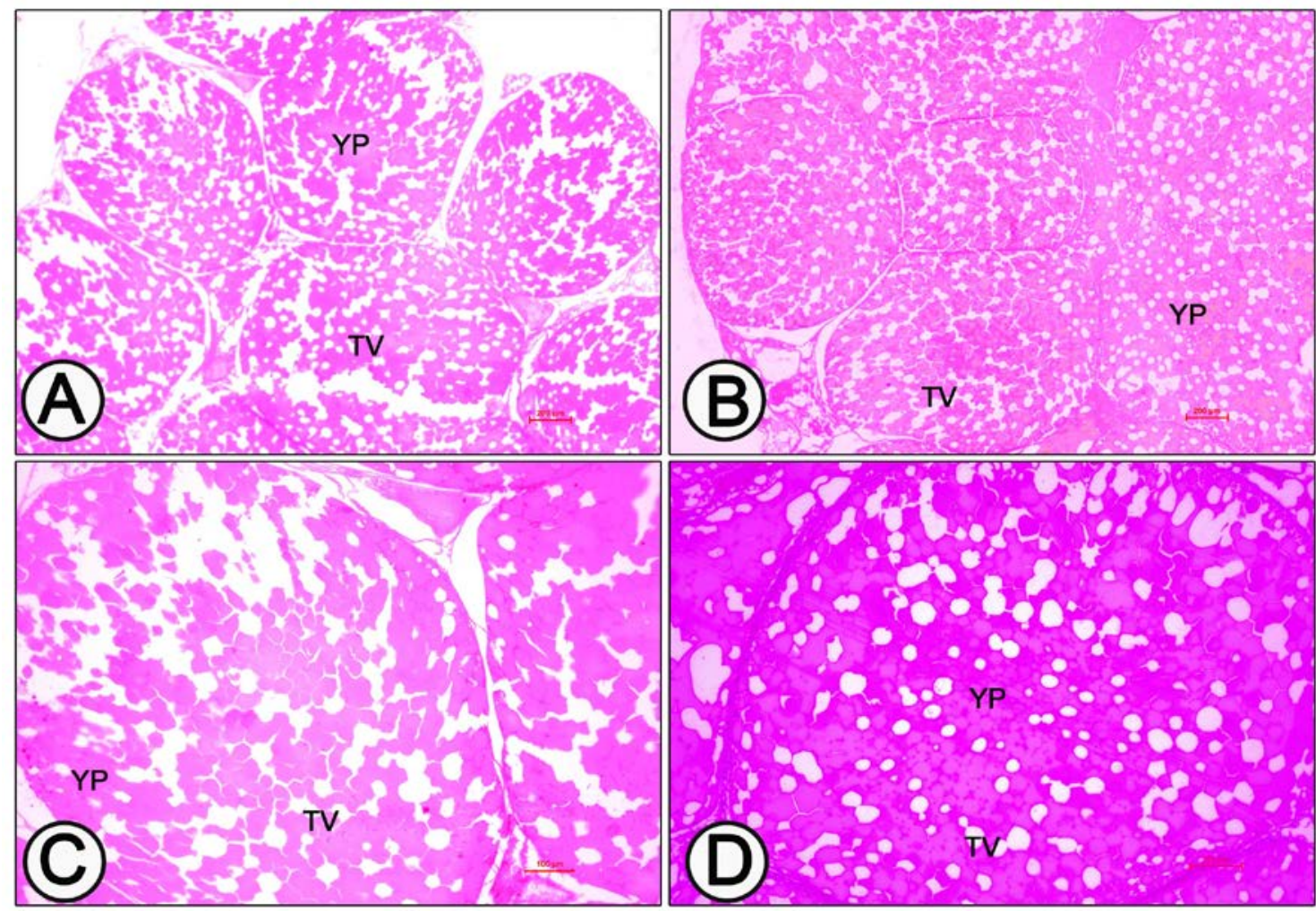

Figure 6. Ovaries of control and 20-0H ecdysone administered T. schirnerae during late vitellogenic phase. (A-B) Control and treated ovary packed with tertiary vitellogenic oocytes (C-D) Tertiary vitellogenic oocytes at higher magnification in control and treated crabs. TV: Tertiary vitellogenic oocyte; YP: Yolk platelet.

\section{Discussion}

Our observations present enough evidence that 20-OH ecdysone administration accelerated ovarian growth in all phases of development of the ovary except during the late vitellogenic phase as evidenced from the elevated gonadosomatic index, mean oocyte diameter and oocyte proportion values, presence of vitellogenic oocytes in prereproductive ovaries and the degree of yolk deposition in vitellogenic oocytes of experimental crabs over the controls.

The present study observed an increase in gonadosomatic index, oocyte diameter and oocyte proportion values in crabs treated with 20-0H ecdysone. Incongruous observations were made by scientists regarding the role of ecdysteroids on reproduction in crustaceans. Several authors suggested steroid $(17 \alpha-\mathrm{OH}$ progesterone and estradiol) induced enhancement in ovarian indices and oocyte diameters in Litopenaeus vannamei, Procambarus clarkii and Oziotelphusa senex senex (Tsukimura and Kamemoto, 1988; Rodriguez et al., 2002; Sujathamma and Dayakar, 2015; Reddy et al., 2006, 2016; Swetha et al., 2016). Administration of $17 \alpha-\mathrm{OH}$ pregnenolone as well as $17 \alpha-\mathrm{OH}$ progesterone stimulated ovarian index, oocyte diameter and ovarian maturity in S. olivacea (Muhd-Farouk et al., 2016). The increase in GSI and oocyte diameter in 20-0H ecdysone injected crabs compared to the controls in the present study is suggestive of the increased yolk deposition enticed by 20-0H ecdysone.

The involvement of vertebrate type steroid hormones in boosting up ovarian growth have been suggested by 
several authors (Nagabhushanam et al., 1987; Sarojini et al., 1990; Zapata et al., 2003; Kale et al., 2008). Couch et al. (1987) noticed a high level of $17 \beta$-estradiol in developing ovaries of crustaceans. Progesterone, estrone or $17 \beta$-estradiol stimulated vitellogenesis was observed in both freshwater (Sarojini et al., 1985, 1986) and marine penaeids (Kulkarni et al., 1979; Nagabhushanam et al., 1980; Yano, 1987; Van Herp and Payen, 1991). Reddy et al. (2006) and Kale (2017) described the 17 $\alpha-\mathrm{OH}$ progesterone and $\beta$-estradiol influenced increase in ovarian index, oocyte diameter, ovarian growth and vitellogenin synthesis in the freshwater crabs $O$. senex senex and B.cunicularis. In S. olivacea, Muhd-Farouk et al. (2014) reported enhanced growth of ovary on administration of $17 \alpha-\mathrm{OH}$ progesterone and $17 \alpha-\mathrm{OH}$ pregnenolone. Medesani et al. (2015) observed significantly increased ovarian indices and vitellogenin levels in female Neohelice granulata fed with $17 \alpha-\mathrm{OH}$ progesterone pelleted feed. In the tiger prawn Penaeus monodon, in vivo and in vitro administration of $17 \beta$-estradiol and $17 \alpha$ $\mathrm{OH}$ progesterone persuaded vitellogenesis and ovarian maturation (Merlin et al., 2015). Oogenesis was hastened in Parapenaeopsis stylifera and Chasmagnathus granulata administered with steroid hormones (Nagabhushanam et al., 1987: Zapata et al., 2003). On the other hand, Rodriguez et al. (2002) and Okumura and Sakiyama (2004) observed a negative correlation between ovarian maturation and vertebrate steroids in P. clarkii and Marsupenaeus japonicus.

In the present study, 20-OH ecdysone treatment caused the production of vitellogenic oocytes in avitellogenic and previtellogenic ovaries and secondary vitellogenic oocytes in early vitellogenic ovaries. In other words, 20-OH ecdysone treatment stimulated avitellogenic and previtellogenic ovaries to grow into vitellogenic ovaries. Moreover, the degree of yolk deposition was high in vitellogenic oocytes of treated crabs than their corresponding controls. Similar research has been carried out by Swetha et al. (2016) in 0 senex senex wherein previtellogenic females reached vitellogenic stage III when administered with $17 \beta$-estradiol and progesterone. In L. vannamei, Chan (1995) noticed a high 20-OH ecdysone titre in the early stages of development of the ovary. Lachaise and Hoffmann (1981) identified three ecdysteroids: ecdysone, 20-OH ecdysone and ponasterone $\mathrm{A}$ in $C$. maenas ovary during early maturation stages. The hemolymph vitellogenin level was found parallel to the ecdysteroid titre during vitellogenesis in isopods and amphipods suggesting its role in vitellogenin synthesis (Steel and Vafopoulou, 1998). Conversely, De Meusy (1962) demonstrated a total non-intervention of ecdysteroids in vitellogenesis in $C$. maenas where Y-organectomy could not cease vitellogenesis. Crompton (1967) noticed a reticence in the production of 20-OH ecdysone during maturation phase and accrual of other ecdysteroids during immature phase ovary.Laufer et al. (1988) and Young et al. (1993) observed a reduction in hemolymph ecdysteroid titre during vitellogenesis in Libinia emarginata and $P$. monodon. Gunamalai et al. (2003) described the exclusion of ecdysteroids by ovary during vitellogenesis in Emerita asiatica.

The current study also observed an increase in the proliferation of oogonia and follicle cells following $20-\mathrm{OH}$ ecdysone administration. In crustaceans, progesterone induced the development of germ cells and gonia was reprted by Brandau (1970) and Joshi (1980). In C. maenas, Arvy et al. (1954) established the involvement of ecdysteroids in the proliferation of young oocytes. Chaix and De Reggi (1982) suggested the possible involvement of ecdysteroids in the continuation of oocyte meiosis in A. lunulatus and Palaemon serratus (Lanot and Cledon, 1989). On the contrary, in $M$. rosenbergii, the level of ecdysteroid was kept minimum during 
the development of the ovary (Okumura and Aida, 2000).

\section{Conclusions}

Though the traditional practice of eyestalk ablation can induce precocious growth and maturation of ovary and spawning in crustaceans, it is often associated with high mortality, inferior quality seed and poor hatchability. An alternate to this is the use of several nonsurgical procedures like the administration of steroid hormones or stimulatory neurotransmitters either as injections or as feed supplements. The outcome of the present study is quite promising which can be exploited in the aquaculture practice of this edible crab.

\section{Acknowledgments}

The financial support provided by the Kerala State Council for Science Technology \& Environment (Order No. P 115/2016/KSCSTE, dated 03-05-2016) in carrying out this research is gratefully acknowledged.

\section{Conflict of interest}

The authors declare that there is no conflict of interest.

\section{References}

Adiyodi, R. G.; Subramoniam, T. Arthropoda: Crustacea. In: Adiyodi, K. G.; Adiyodi, R. G. (Eds). Reproductive Biology of Invertebrates. Vol. I Oogenesis, oviposition and oosorption. New York: John Wiley and Sons, 1983. p. 443-495.

Arvy, L.; Echalier, G.; Gabe, M. Modifications de la gonade de Carcinus maenas apres ablation bilaterale de l'organe Y. Comptes Rendus de l'Académie des Sciences, Serie D, v. 239, p. 1853-1855, 1954.

Blanchet-Tournier, M. F. Quelques aspects des interactions hormonales entre la mue et la vitellogenèse chez le Crustacé Amphipode Orchestia gammarellus (Pallas).
Reproduction Nutrition Development, v. 22, no. 2, p. 325-344, 1982.

Brandau, H. Histochemical localization of enzyme activities in normal and gonadotrophin stimulated mouse ovaries. In: Butt, W. R.; Crooke, A. C.; Ryle, M. (Eds.). Gonadotrophins and Ovarian Development. Livingstone, Edinburgh, London: Eshkol, A., Lunenfeld, B., and Pet, 1970. p. 307-311.

Brown, M.; Sieglaff, D.; Rees, H. Gonadal ecdysteroidogenesis in Arthropoda: Occurrence and regulation. Annual Review of Entomology, v. 54, p. 105-125, 2009. https://doi.org/10.1146/annurev.ento.53.10 3106.093334

Chaix, J. C.; De Reggi, M. Ecdysteroid levels during ovarian development and embryogenesis in the spider crab Acanthonyx lunulatus. General and Comparative Endocrinology, v. 47, no. 1, p. 7-14, 1982. https://doi.org/10.1016/00166480(82) $90076-4$

Chan, S. M. Possible roles of 20hydroxyecdysone in the control of ovary maturation in the white shrimp Penaeus vannamei (Crustacea: Decapoda). Comparative Biochemistry and Physiology - Part C: Toxicology \& Pharmacology, v. 112, no. 1, p. 51-59, 1995. https://doi.org/10.1016/0742-8413(95) 00073-9

Chang, E. S. Hormonal control of molting in decapod Crustacea. American Zoologist, v. 25, no. $1, \quad$ p.179-185, 1985. https://doi.org/10.1093/icb/25.1.179

Couch, E. F.; Hagino, N.; Lee. J. W. Changes in estradiol and progesterone immunoreactivity in tissues of the lobster, Homarus americanus, with developing and immature ovaries. Biochemistry and Physiology Part A: Molecular \& Integrative Physiology, v. 87, no. 3, p. 765-770, 1987. http://doi.org/ 10.1016/0300-9629(87)90397-5

Crompton, D. W. Studies on the haemocytic reaction of Gammarus spp., and its relationship to Polymorphus minutus (Acanthocephala). Parasitology, v. 57, n. 2, p. 389-401, 1967. https://doi.org/10.1017/ S0031182000072176

Démeusy, N. Rôle de la gland de mue dans l'évolution ovarianne due crabe Carcinus 
maenas Linn. Cahiers de Biologie Marine, v. 3, p. 37-56, 1962.

Gong, J.; Ye, H.; Xie, Y.; Yang, Y.; Huang, H.; Li, S.; Zeng, C. Ecdysone receptor in the mud crab Scylla paramamosain: A possible role in promoting ovarian development. Journal of Endocrinology, v. 224, no. 3, p. 273-287, 2015. https://doi.org/10.1530/JOE-14-0526

Gunamalai, V.; Kirubagaran, R.; Subramoniam, T. Sequestration of ecdysteroid hormone into the ovary of the mole crab, Emerita asiatica (Milne Edwards). Current Science, v. 85, no. 4, p. 493-496, 2003.

Kale, R. S.; Shejule, K. B.; Kharat, P. S.; Sonawane, A. K. Induce ovarian maturation by $17 \alpha$-hydroxyprogesterone hormone in freshwater crab, Barytelphusa cunicularis. Journal of Aquatic Biology, v. 23, no. 2, p. 109-112, 2008.

Kale, R. S. Effect of $\beta$-estradiol hormone and eye stalk ablation on ovarian maturation in fresh water crab, Barytelphusa cunicularis. Bioscience Discovery, v. 8, no. 2, p. 140-145, 2017.

Kulkarni, G. K.; Nagabhushanam, R.; Joshi, P. K. Effect of progesterone on ovarian maturation in a marine penaeid prawn Parapenaeopsis hardwickii (Miers, 1878). Indian Journal of Experimental Biology, v. 17, p. $986-987,1979$.

Lachaise, F.; Hoffmann, J. A. Ecdysone et developement ovarien chez un Decapode, Carcinus maenas. Comptes Rendus de l'Académie des Sciences, Serie D, v. 285, p. 701-704, 1981.

Lachaise, F.; Goudeau, M.; Hetru, C.; Kappler, C.; Hoffmann, J. A. Ecdysteroids and ovarian development in the shore crab, Carcinus maenas. Hoppe-Seyler's Zeitschrift für Physiologische Chemie, v. 362, no. 1, p. 521-530, 1981. https://doi.org/10.1515/ bchm2.1981.362.1.521

Lanot, R.; Cledon P. Ecdysteroids and meiotic reinitiation in Palaemon serratus (Crustacea Decapoda Natantia) and in Locusta migratoria (Insecta Orthoptera): A comparative study. Invertebrate Reproduction \& Development, v. 16, no. $1 / 3$, p. $169-175$, 1989. http://doi.org/ 10.1080/07924259.1989.9672074
Laufer, H.; Ahl, J. S.; Sagi, A. The role of juvenile hormones in crustacean reproduction. American Zoologist, v. 33, no. 3, p. 365-374, 1993. https://doi.org/ $10.1093 / \mathrm{icb} / 33.3 .365$

Laufer, H.; Borst, D. W.; Foley, T. A.; Landau, M. Ecdysteroid titres in vitellogenic Libinia emarginata. Journal of Insect Physiology, v. $34, \quad$ no. $7, \quad$ p. 615-617, 1988. https://doi.org/10.1016/0022-1910(88) 90068-6

Medesani, D. M.; Ferre, L. E.; Canosa, I. S.; Silveyra, G. R.; Rodriguez, E. M. Induction of vitellogenesis by 17-hydroxyprogesterone and methyl farnesoate during postreproductive period, in the estuarine crab Neohelice granulata. Invertebrate Reproduction \& Development, v. 59, no. 2, p. 1-7, 2015. http://doi.org/10.1080/ 07924259.2015 .1019014

Merlin, J.; Mohanlal, D. L.; Balasubramanian, C. P.; Sherly, T.; Subramoniam, T.; Syamadayal, J.; Ravichandran, P.; Ponniah, A. G.; Gopal, C.; Vijayan, K. K. Induction of vitellogenesis and reproductive maturation in tiger shrimp, Penaeus monodon by $17 \AA-$ estradiol and 17 $\alpha$-hydroxyprogesterone: In vivo and in vitro studies. Invertebrate Reproduction \& Development, v. 59, no. 3, p. 166-175, 2015. http://doi.org/10.1080/ 07924259.2015 .1051192

$\mathrm{Mu}$, C.; Song, W.; Li, R.; Chen, Y.; Hao, G.; Wang, C. Identification of differentially expressed proteins relating to ovary development in Portunus trituberculatus. Aquaculture, v. 426, p. 148-153, 2014. https://doi.org/10.1002/jat.2965

Muhd-Farouk, H.; Abol-Munafi, A.; Jasmani, S.; Ikhwanuddin, M. Effect of steroid hormones $17 \alpha$-hydroxyprogesterone and $17 \alpha$-hydroxypregnenolone on ovary external morphology of orange mud crab, Scylla olivacea. Asian Journal of Cell Biology, v. 9, p. 23-28, 2014. http://doi.org/10.3923/ ajcb.2014.23.28

Muhd-Farouk, H.; Jasmani, S.; Ikhwanuddin, M. Effect of vertebrate steroid hormones on the ovarian maturation stages of orange mud crab, Scylla olivacea (Herbst, 1796). Aquaculture, v. 451, p. 78-86, 2016. https://doi.org/10.1016/j.aquaculture.2015. 08.038 
Nagabhushanam, R.; Sambasivarao, S.; Sarojini, R.; Jayalakshmi, K. Annual reproductive cycle of female Metapenaeus affinis. Proceeding of the National Symposium on Physiology of Crustaceans, p. 39-41, 1987.

Nagabhushanam, R.; Joshi, P. K.; Kulkarni, G. $\mathrm{K}$. Induced spawning in prawn Parapenaeopsis stylifera (H. Milne Edwards) using a steroid hormone 17 hydroxyprogesterone. Indian Journal of Marine Sciences, v. 9, p. 227, 1980. http://doi.org/ $123456789 / 39227$

Okumura, T.; Sakiyama, K. Hemolymph levels of vertebrate-type steroid hormones in female kuruma prawn Marsupenaeus japonicus (Crustacea: Decapoda: Penaeidae) during natural reproductive cycle and induced ovarian development by eyestalk ablation. Fisheries Science, v.70, p. 372380, 2004.

Okumura, T.; Aida, K. Fluctuations in hemolymph ecdysteroid levels during the reproductive and non-reproductive molt cycles in the giant freshwater prawn Macrobrachium rosenbergii. Fisheries Science, v. 66, no. 5, p.876-883, 2000. https://doi.org/10.1046/j.1444-2906.2000. 00142.x

Okumura, T.; Han, C. H.; Suzuki, Y.; Aida, K.; Hanyu, I. Changes in hemolymph vitellogenin and ecdysteroid levels during the reproductive and non-reproductive molt cycles in the freshwater prawn Macrobrachium rosenbergii. Zoological Science, v. 9, p. 37-45, 1992.

Reddy, B. S.; Sridevi, V.; Neelima, H.; Reddy, P. R.; Reddy, P. S. Regulation of vitellogenesis by selected endocrine modulators in crab Oziothelphusa senex senex, with special reference to methyl farnesoate. Aquaculture Reports, $\quad$ v. 3, p. 24-30, 2016. https://doi.org/10.1016/j.aqrep.2015.11.006

Reddy, P. R.; Kiranmayi, P.; Kumari, K.; Reddy, P.S. 17 $\alpha$-hydroxyprogesterone induced ovarian growth and vitellogenesis in the freshwater rice field crab Oziotelphusa senex senex. Aquaculture, v. 254, no. 1/4, p. 768-775, 2006. https://doi.org/10.1016/ j.aquaculture.2005.11.023

Rodríguez, E. M.; Medesani, D. A.; Greco, L. S. L.; Fingerman, M. Effects of some steroids and other compounds on ovarian growth of the red swamp crayfish, Procambarus clarkii, during early vitellogenesis. Journal of Experimental Zoology, v. 292, no. 1, p. 8287, 2002. https://doi.org/10.1002/jez.1144

Sarojini, R.; Jayalakshmi, K.; Sambashivarao, S. Effect of external steroids on ovarian development in the freshwater prawn Macrobrachium lamerrii. Journal of Advanced Zoology, v. 7, no. 1, p. 50-53, 1986.

Sarojini, R.; Mirajkar, M. S.; Nagabhushanam, R. Effect of steroids on the oogenesis and spermatogenesis of the freshwater prawn, Macrobrachium kistnensis. Comparative Physiology and Ecology, v. 10, no. 1, p. 7-11, 1985.

Sarojini, R.; Sambasivarao, S.; Jayalakshmi, K. Effect of steroids (Estradiol and estrone) on the ovaries of the marine crab, Scylla serrata. Comparative Physiology and Ecology, v. 15, no. 1, p. 21-26, 1990.

Steel, C. G. H.; Vafopoulou, X. Ecdysteroid titres in haemolymph and other tissues during moulting and reproduction in the terrestrial isopod, Oniscus asellus (L.). Invertebrate Reproduction \& Development, v. 34 , no. $2 / 3$, p. 187-194, 1998. https://doi.org/10.1080/07924259. 1998.9652652

Subramoniam, T. Crustacean ecdysteroids in reproduction and embryogenesis. Comparative Biochemistry and Physiology - Part C: Toxicology \& Pharmacology, v. 125 , no. 2, p. $135-156$, $2000 . \quad$ https://doi.org/10.1016/S07428413(99)00098-5

Sujathamma, A.; Dayakar, Y. Effect of estradiol and $17 \alpha$-hydroxyprogesterone on ovarian development of freshwater paddy field crab, Oziotelphusa senex senex (Fabricius). European Journal of Experimental Biology, v. 5, n. 9, p. 27-30, 2015.

Swetha, C. H.; Girish, B. P.; Reddy, P. S. Elucidation of the role of estradiol and progesterone in regulating reproduction in the edible crab, Oziothelphusa senex senex. RSC Advances, v. 6, no. 30, p. 24959-24967, 2016. https://doi.org/10.1039/C5RA23637A

Tsukimura, B.; Kamemoto, F. L. Organ culture assay of the effects of putative reproductive hormones on immature penaeid ovaries. The 
World Aquaculture Society Abstract, v. 288, 1988.

Van Herp, F.; Payen, G. G. Crustacean neuroendocrinology: Perspectives for the control of reproduction in aquacultural systems. Bulletin of the Institute of Zoology, Academia Sinica, v. 16, p. 513-539, 1991.

Wongsawang, P.; Phongdara, A.; Chanumpai, A.; Chotigeat, W. Detection of $\mathrm{CHH} / \mathrm{GIH}$ activity in fractionated extracts from the eyestalk of Banana prawn. Songklanakarin Journal of Science and Technology, v. 27, p. 789-798, 2005.

Yano, I. Effect of 17-hydroxy-progesterone on vitellogenin secretion in kuruma prawn, Penaeus japonicus. Aquaculture, v. 61, p. 4957, 1987.

Young, N. J.; Webster, S. G.; Rees, H. H. Ecdysteroid profiles and vitellogenesis in Penaeus monodon (Crustacea: Decapoda). Invertebrate Reproduction \& Development, v. 24, no 2, p. 107-117. 1993. https://doi.org/10.1080/07924259.1993.96 72340

Yudin, A. I.; Diener, R. A.; Clark, Jr. W.; Chang, E. S. Mandibular gland of the blue crab, Callinectes sapidus. The Biological Bulletin, v. 159, p. 760-772, 1980.

Zapata, V.; Lopez Greco, L. S.; Medesani, D.; Rodriguez, E. M. Ovarian growth in the crab, Chasmagnathus granulata induced by hormones and neuroregulators throughout the year: In vivo and in vitro studies. Aquaculture, v. 224, no. 1/4, p. 339. 2003. http://doi.org/10.1016/S0044-8486(03) 00226-6 